DOI: https://doi.org/10.47405/mjssh.v6i10.1106

\begin{tabular}{|c|c|}
\hline 4 & Malaysian Journal of Social Sciences and Humanities (MJSSH) \\
\hline $\begin{array}{l}\text { Malaysian Juoural of } \\
\text { Social ccciecces and }\end{array}$ & Volume 6, Issue 10, October 2021 \\
\hline (MJ-sSH) & e-ISSN : 2504-8562 \\
\hline & $\begin{array}{l}\text { Journal home page: } \\
\text { www.msocialsciences.com }\end{array}$ \\
\hline
\end{tabular}

\title{
Family Addressing System in Malay and Arab Languages: An Analysis of Sociolinguistic Clash
}

\author{
Muhamad Zaidi Zakaria' ${ }^{1}$, Abdul Azim Mohamad Isa', Muhammad Arsyad Abdul Majid", \\ Ibrahim Abdullah' ${ }^{1}$, Asma' Ammar' ${ }^{1}$ \\ ${ }^{1}$ Akademi Pengajian Bahasa, Universiti Teknologi MARA (UiTM), Malaysia
}

Correspondence: Muhamad Zaidi Zakaria (muhazaidi@uitm.edu.my)

\begin{abstract}
This study is a first attempt to comparatively study the addressing system in Malay and Arabic societies, which is an important element in communicating and interacting. This analysis uses lexicological and sociolinguistic approaches. The study found that the family addressing system in Arabic is viewed as more complicated and complex than the address forms used within the Malay society. This will cause difficulty and confusion in determining the appropriate meaning match for the terms. As a result, translators and anyone else involved in the process of moving the meaning of a word between Malay and Arabic should be cautious and always refer to the term's meaning before assigning a match so that the receiver or reader of the translation do not become confused.
\end{abstract}

Keywords: family addressing system, sociolinguistic clash, Malay and Arabic languages

\section{Introduction}

Every word has a meaning, and that meaning must be clear and comprehensive in order for individuals who do not speak the same language as the term to understand it. Hence, the meaning, and determining the match of the meaning, are elemental in measuring the efficacy of communication relationship of a language speaker with another.

Some linguists have asserted that every lexical in one language has an equivalent meaning in another. Nonetheless, they recognise that, while there are certain parallels in the classification of lexical according to specific categories of meaning, identifying the meaning of a lexical for a language in another language remains challenging. Finding the exact meaning match for a term is challenging, but not impossible; the question is whether the translation of a language presents the meaning match that is closest to the meaning of the source language.

This could be attributed to a variety of circumstances. Cultural distinctions across languages are one of them, with terminology that only exist in the cultural framework of one society and not in the culture of another. This linguistic phenomenon has piqued the interest of experts who want to learn more about why this phenomenon arises and what elements contribute to it. The properties found on the lexical items implicated in this phenomenon are listed as below. 


\section{Objectives}

Describe the lexical traits that make it difficult for users of both languages to identify the right meaning match for the lexical items. Review the factors influencing the difference of meaning match in the Arabic and Malay family addressing terms.

\section{Limitations Of Study}

This research focuses solely on the phenomena of meaning matching as viewed in the context of family addressing terms in both languages. In doing the study on the equivalence of meanings, the meaning of the equivalence match in Arabic and Malay, the meaning of the equivalence match among linguistics scholars and their arguments about it will be discussed. This research will also look at how far linguistic experts have looked into the issue of meaning matching.

\section{Research Methodology}

This study is limited to library research due to the subject chosen. This study was limited to library research due to the subject chosen. To meet the study's requirements, data from the first edition of the Kamus Besar Arab-Melayu Dewan (KBAMD) will be used as the primary source in the data collection. To obtain essential data from the monolingual Arabic dictionary, the researcher used the alMunjid dictionary as a reference. Both dictionaries have been adopted since the KBAMD dictionary is the most recent and viewed to contain the most entry among Arabic-Malay dictionaries. Al-Munjid, on the other hand, has both traditional and contemporary features. In addition, for research purposes, books on Arabic and Malay linguistics will also be used as references.

\section{Data Analysis}

The data processing in this research is contrastive. Consequently, the data will be analysed using a comparison technique. The goal of this procedure is to collect data that is complete, parallel, and accurate. Conclusions for the entire study were drawn from observations of the obtained data as well as the analysis performed.

\section{Malay-Arab Family Terminology Equivalence}

Here are some examples of family terminology equivalence that researchers would like to explore:

\section{i. Lexical of}

According to the Kamus Besar Arab-Melayu Dewan (KBAMD, 2006:22), the term ألَا carries four

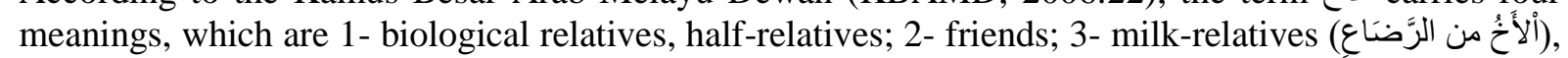
4- partners, equals, and; 5- team members. The question arises because in the Malay culture, people who have family links but are not siblings are referred to as 'relatives'. Some are called 'close relatives' while some are called 'distant relatives'. Are these groups can also be categorised as $\mathcal{c}^{\prime}{ }^{\prime}$ ? In this regard, the researcher would like to quote an Arabic proverb that goes:

Indeed, your relatives are those who sympathise with you (al-Mayda:niyy 512H:72)

In this proverb, Arabs are also seen identifying 'relatives' as everyone who is sympathetic and does not harm us. As a result, it encourages us to value everyone we consider a relative. Another proverb that more clearly demonstrates the range of meaning associated with the use of $\hat{z}^{\prime}{ }^{i}$ is:

It might just be that your relative is the one who was not born by your mother (al-Mayda:niyy 512H:291) 
Therefore, the term ألأَ has a broader definition that includes anybody who is liked and is not restricted to those with biological links. Regardless, the plural form of 'relatives' that connotes 'siblings' (Abu Abdul, 1996:3). Meanwhile, the term iألفَّرَبَاءُ is defined as 'close siblings'. At the same time, the term iالَادنُْنُن is used and carries the same meaning (Zaidan,

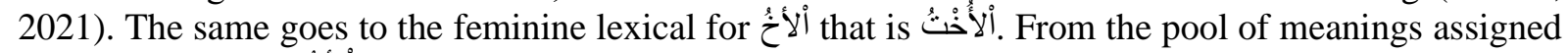
above on the term 'it, it can be concluded that the 'biological relatives' are only denoted to only the half-relatives or half-siblings. How about the full-relatives or full-siblings (sharing the same parents)?

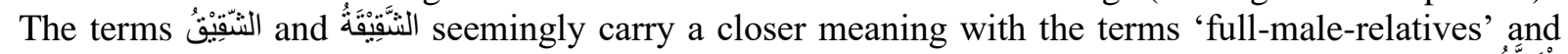
'full-female-relatives. Besides, there are other terms used in referring to 'full-relatives' which are (KBAMD, 2006:1898) and الصِينّوُ (KBAMD, 2006:1371).

From the conducted analysis, it can be concluded that the term 'relatives' in Malay. However, considering the context of 'relatives' that carry a broader sense of

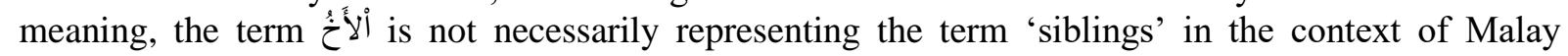
language, despite the term 'siblings' might as well comprised in the 'relatives' scope. To put it another way, all relatives are like siblings, but not all siblings are like relatives. A more appropriate term to be used in referring to 'siblings' is الثَّقِيقُ . The table below may help to understand the previous conclusions.

\section{ii. Lexical of}

This lexical provides the meaning of 'father' or 'dad for the word (KBAMD, 2006: 8). Yet it is also used to mean 'grandfather', 'uncle' (not specified maternal uncle or paternal uncle) and 'owner' as quoted from Mu'jam al-Wasit.

While the term الْابََوَانُ carries the meaning of 'father and mother' (al-Wasit:4).

It also denotes 'father' and 'uncle' (KBAMD, 2006:8).

The table below specifies the pool of meanings for lexical الْالََوَان :

Table 1: Pool of meanings for terms ألأَبَوَانُ الَأَبُ and

\begin{tabular}{|c|c|c|c|c|c|c|}
\hline & Father & $\begin{array}{l}\text { Grand- } \\
\text { father }\end{array}$ & $\begin{array}{l}\text { Grand- } \\
\text { parents }\end{array}$ & $\begin{array}{l}\text { Father \& } \\
\text { Mother }\end{array}$ & $\begin{array}{l}\text { Father \& } \\
\text { Uncle }\end{array}$ & $\begin{array}{l}\text { Father \& } \\
\text { Grand-father }\end{array}$ \\
\hline ألأبُ & & & & & & \\
\hline ألالَبَوَانُ & $\sqrt{ }$ & $\sqrt{ }$ & $\sqrt{ }$ & $\sqrt{ }$ & $\begin{array}{l}\sqrt{ } \\
\sqrt{ }\end{array}$ & $\sqrt{ }$ \\
\hline
\end{tabular}

From the classification conducted on the term iالَبَّ, it can be summarised that this term essentially matches the meaning of 'father' in the Malay, with the expanded usage to the meanings of 'father', 'grandfather', 'grandparents', 'uncle' and 'parents'.

\section{iii. Lexical of الْحَمَى}

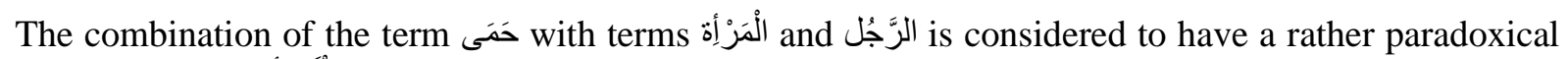

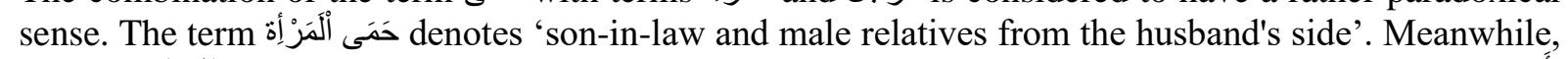

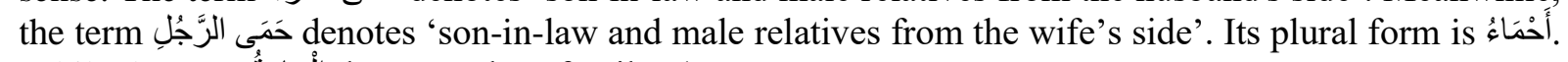

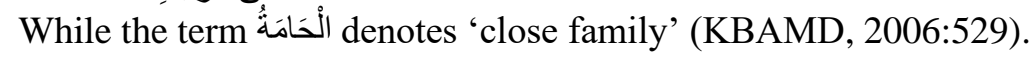

From what has been presented thus far, it can be deduced that the term الْحَمَى has the meanings of 'sonin-law' and 'male relatives'. Apart from الْحَىَى

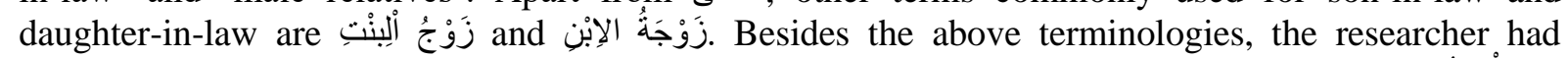
discovered a couple of lexical that are considered more accurate to define 'in-laws', which is الََََْْ for son-in-law and الْخَنَّنَّة for daughter-in-law (KBAMD, 2006:574). 


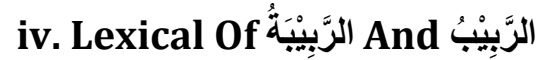

These lexical terms denote 'female stepdaughter' and 'male stepdaughter', respectively. The meaning matching, without a doubt, is correct. However, there is another term that is more closely associated with the term 'male stepson', which is 'الََْرَل '(wife's son of the first husband) (al-Munjid:863). While the comparable meanings of the terms 'stepfather' and 'stepmother' in the al-Marbawi Dictionary are

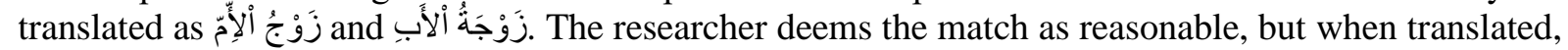
it appears to favour the explanations of 'husband to mother' and 'wife to father'. It would be preferable if we could use the terms الَّرابُ for 'stepfather' and الرَّابَّةُ for 'stepmother' (KBAMD, 2006: 841 ) since it is considered to be more brief and compact.

\section{v. Lexical of الْعَمَ And الَْالَ}

In most cases, a language lacks a term that accurately expresses the true meaning of a term in another language. It occurred in the Malay language when there is no specific phrase matching the terms

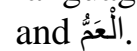

These two terms are merely translated as 'maternal uncle' and 'paternal uncle', respectively. Likewise,

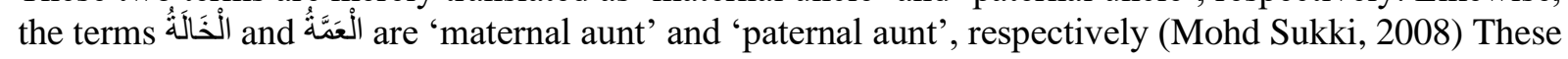
two terms are merely translated as 'maternal uncle' and 'paternal uncle,' respectively. Similarly, the terms 'maternal aunt' and 'paternal aunt' are 'maternal aunt' and 'paternal aunt,' respectively (Mohd Sukki Othman : 2008). A similar situation happened with the term 'cousin,' where the Malay language lacks a term to distinguish between male maternal cousin, male paternal cousin, female maternal cousin and female paternal cousin, whereas in Arabic, we get to distinguish these callings through the terms:

$$
\begin{aligned}
& \text { : : : : male paternal cousin } \\
& \text { : : : male maternal cousin } \\
& \text { : : : female paternal cousin } \\
& \text { : : female maternal cousin }
\end{aligned}
$$

\section{Malay-Arab Family Terminology Equivalence}

The Malay language is known for its courtesy and politeness in discourse. It represents the Malay culture's emphasis on decent and orderly behaviour as well as attitude. As a result, in family connections, the terminology used in conversation should be appropriate for the respondent. The researcher aims to introduce some terminology within the Malay family addressing system, which is perceived to be more unique and complex than Arabic.

After explaining the addressing terms, the researcher moves on to family calling names, where the Malay language has a system of family calls that is unique from Arabic and other languages. In the Malay language, there are numerous family calls; in fact, Kalthum and Sabariah (2016) documented the Malay family addressing system in dialects from various states in a study. The family calls such as pak (father), mak (mother), akak (elder sister) dan adik (little brother/sister) are used not only in blood or marriage-related family relationships, but also outside the family connections, particularly in informal interactions with friends, relatives of friends, villagers, and so on (Marlyna, Aslinda, Mohd Baharim, 2010.). The use of family nicknames symbolises harmony, closeness and courtesy. Family nicknames basically consist of: abang/bang (elder brother), kakak/kak (older sister), adik (little brother/sister), anak (son/daughter), bapa/pak/ayah (father), ibu/emak/mak (mother), cucu (grandson/granddaughter), cicit (great-grandson), datuk/tok (grandfather), nenek/wan (grandmother) dan moyang (ancestor). All of these basic family calls can be prefixed by the name of the person, such as Bang Mad, Pak Ali, Mak Yah and so on (Kalthum \& Sabariah, 2016).

Only the lexical pak and mak, respectively, have an appropriate match in the Arabic call system, which

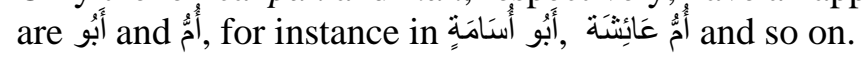


The Malay language specifies distinct names for an older and younger male relative, which are abang and adik lelaki, respectively. Thus, when the lexical abang is used, it conjures up images of the elder brother, whereas when the lexical adik lelaki is used, it conjures up images of the little brother. In

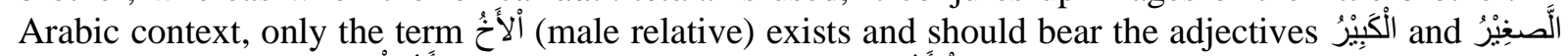

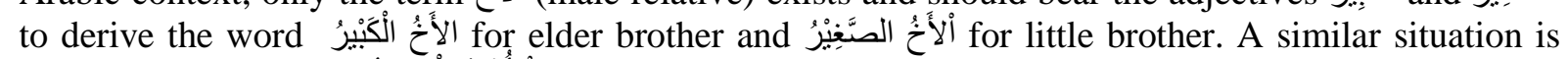

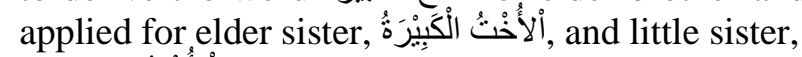

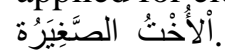

\section{Summary}

The researcher has drawn certain summaries and conclusions upon discussing and analysing all of the data and information gathered during the development of this study. Among them are the following:

Determining the meaning of a phrase is challenging. It is required to look at the context of usage in the sentence to comprehend the meaning of a word, term, or expression. The relationship of meaning between words in a sentence can aid in the comprehension of a term's meaning. Furthermore, finding a true meaning match necessitates a high level of observation, experience, and linguistic sensibility.

Linguistic experts are of differing opinions about whether each word has a meaning match. However, based on the conducted study, the researcher argues as a word has so many diverse meanings, there is no truly accurate meaning match for almost every word. However, this can be dismissed since what matters is the message that a speaker wishes to transmit through the words can be understood by the listener.

When translating something lexical, it is vital to try as much as possible to get the closest and simplest meaning match possible so that individuals who are not native speakers may understand the meaning to be transmitted through the translation language.

The effect of diverse cultures and the environment among speakers of both languages is one of the elements that led to the inaccuracy of meaning equivalence between Arabic and Malay and vice versa. It is perceived that the Malay's terms of family and society callings are more odd and complex than the family callings in the Arab society. This will make identifying the suitable meaning match for the phrases difficult and confusing.

Although determining the meaning match of certain lexical items in both languages can be difficult, the phenomenon of diversity of meaning characteristics from other angles can help users of both languages obtain various information - gender, position in family and society, status, and so on - all from a single lexical item.

Strictly speaking, finding a compatible and accurate match for a word in regards to all perspectives is impossible. Therefore, translators and anyone else involved in shifting the meaning of a word in Malay and Arabic, including language teachers, must be cautious and always refer to a term before assigning the match, ensuring the receiver or reader of the translation of the words are not confused.

\section{References}

Florian Coulmas. (2013). Sociolinguistics: The Study of Speakers' Choices. New York: Cambridge University Press.

Kalthum Ibrahim \& Sabariah Mohd Ghani. (2016). Kata Panggilan Kekeluargaan oleh Mahasiswa dari Pantai Timur Universiti Kebangsaan Malaysia; Satu Kajian Sosiolinguistik. Jurnal Linguistik, 20(1), 001-009. 
DOI: https://doi.org/10.47405/mjssh.v6i10.1106

Marlyna Maros, Aslinda John, \& Mohd Baharim Mydin. (2010). Pola Sapaan Pelajar Lelaki dan Perempuan di Sebuah Institusi Pengajian Tinggi: Satu Kajian Sosiopragmatik. GEMA Online Journal of Language Studies, 10(2).

Mohd Sukki Othman. (2008). Bahasa Arab Mudah Jikalau Faham Budaya Arab dalam Dewan Bahasa Februari 2008. Kuala Lumpur: Dewan Bahasa dan Pustaka.

Norliza Jamaluddin. (2003). Sistem Panggilan Masyarakat Melayu Sarawak. Kuala Lumpur: Dewan Bahasa dan Pustaka.

Zaidan Ali Jassem. (2021). Lectures In English And Arabic Sociolinguistics: Language Change, Death \& Rebirth. Kuala Lumpur : Pustaka Antara. 